陸水学会第 67 回大会：流域と海洋を語る 一流域からの提言・海洋からの提言一 (日本陸水学会・日本水環境学会合同シンポジウム)

\title{
シンポジウム記録 [Record]
}

\section{生物蓄積性内分泌攪乱物質による地球規模の環境污染}

\author{
田辺 信介
}

\section{Global environmental contamination by bioaccumulative endocrine disrupters}

\author{
Shinsuke TANABE ${ }^{1)}$
}

\begin{abstract}
The present paper overviews the global contamination by organochlorines, a representative group of persistent organic pollutants (POPs) and endocrine disrupters, and their ecotoxicological implications on wildlife and humans from Asia. The recent pattern of contamination by organochlorine residues in the coastal environment is prominent in tropical regions due to continuous usage in the low-latitude developing countries. The major emission source of organochlorine insecticides such as DDTs and HCHs is probably located in the tropical belt and large quantities of volatilized contaminants are dispersed through the atmosphere on global terms. Reflecting this, a considerable contamination was observed in open ocean tropical waters as well as in the Arctic and nearby waters. On the other hand, PCBs are mainly released from developed nations and also deposited in open seas and oceans. The study of the mass transfer of organochlorines at the air-water interface suggests that the oceanic water bodies, particularly Arctic waters, act as a sink for persistent contaminants.

Our studies also focus on exposure and toxic effects of POPs, particularly organochlorines, in higher trophic level wildlife from Asia. Endocrine disrupting chemicals, such as organochlorine insecticides, polychlorinated biphenyls (PCBs) etc are found in tissues of a wide variety of wildlife from Asia. In general, water birds and marine mammals accumulated the dioxin-like compounds with much higher concentrations than humans, implying higher risk from exposure to these toxic contaminants in wildlife. The future issues of endocrine disrupting chemicals in humans and wildlife will have to be focused on Asian developing countries.
\end{abstract}

Key words: endocrine disrupters, organochlorines, dioxins, wildlife, marine mammals, marine pollution

摘 要

生物蓄積性内分泌攪乱物質として知られるPCBsやDDTsなど有機塩素化合物による環境污染は地球 規模で拡がり，海洋はこの種の物質の最終的な到達点であり溜まり場として機能することが明らかにさ れている。また生物の污染，なかでもアザラシや鯨，アホウドリなど海棲高等動物の污染は顕在化して おり，大量死など内分泌攪乱物質が原因と思われる異常も多数報告されている。海棲高等動物でみられ る顕著な污染と影響は，一部の薬物代謝酵素系の欠落など，この種の動物の特異な生理機能に原因があ る。ヒトに比べ野生の高等動物は，はるかに高い濃度でダイオキシン類を蓄積しており，そのリスクは ヒトよりも野生生物に扔いて深剢化する怖れがある。内分泌攪乱物質によるヒトや生態系の污染は今後 途上国で拡大する可能性があり，その現状と課題についても紹介する。 キーワード：内分泌攪乱物質, 有機塩素化合物, ダイオキシン, 野生動物, 海棲哺乳動物, 海洋污染

はじめに

化学物質の生産と利用は近年急速な展開をみせ，世界
の年流通額は 1990 年代になって 3,000 億ドルを笑破し た(Anderson, 1993)。この金額がわが国の年間国家予算 の㧍よそ半分に相当することを考えると，物質文明の急

1)愛媛大学沿岸環境科学研究センター †790-8577 愛媛県松山市文京町 2-5. Center for Marine Environmental Studies (CMES), Ehime University, 2-5 Bunkyo, Matsuyama 790-8577, Japan(E-mail: shinsuke@ @agr.ehime-u.ac.jp) 


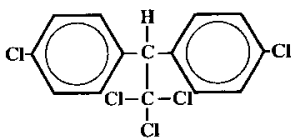

DDT<smiles>ClC1C(Cl)C(Cl)C(Cl)C(Cl)C1Cl</smiles>

HCH

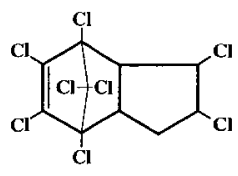

CHL<smiles>Clc1c(Cl)c(Cl)c(Cl)c(Cl)c1Cl</smiles>

HCB

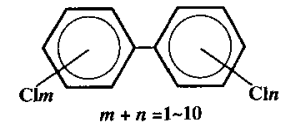

PCBs
Fg. 1. Persistent organochlorines.

図 1. 代表的な有機塩素化合物。

進にあらためて驚かざるをえない。無数ともいえる化学 物質の安全性について，個別に対応し対策を立てること は不可能に近いが，こうした化学物質を環境污染の観点 から整理分類する作業はいくつかの研究機関によって試 みられてきた。ヒトの健康を問題にしたもの，生物蓄積 性に注目したもの，海洋污染を取り上げたものなど視点 は様々であるが，共通していえることは，いずれも有機 塩素化合物が高い位置にランクされていることである。 なかでも代表的な内分泌擋乱物質として知られる PCB (ポリ塩化ビフェニール)やダイオキシンなどは，毒性が 強く，生体内に容易に侵入し，そこに長期間とどまる性 質があるため最も厄介な化学物質として関心を集めてき た。また, DDT(ジクロロジフェニルトリクロロエ夕 ン), $\mathrm{HCH}$ (ヘキサクロロシクロヘキサン: 商品名 BHC)， $\mathrm{CHL}$ (クロルデン), $\mathrm{HCB}$ (ヘキサクロロベンゼン)など 悪名高い農薬も有機塩素化合物の仲間である(Fig. 1)。

生態系への蓄積や影響を矁念し, ほとんどの先進諸国 では有機塩素化合物の生産を禁止したが，その環境污染 は今なお続いており，学術的・社会的関心は依然として 高い。とくに，この種の物質による海洋污染の問題は， 1995 年 11 月に約 100 ケ国の政府代表が参加してワシン トンで開催された「海洋污染防止政府間会合」でもとりあ げられ，污染の拡大を防ぐ具体策の検討が行動計画に盛 り込まれた。また, 国連環境計画(UNEP) は, 有機塩素 化合物による污染が地球規模で広がったことに対処する ため，西暦 2004 年をめどに環境污染を防止する国際条 約 (POPs 条約)の締結を提案している。有機塩素化合物 は，地球規模の環境污染が染刻化し，その防止対策の強 化が国際レベルで求められている最も厄介な化学物質と いってよい。

本稿では, 有機塩素化合物による地球規模の污染とそ
の生態系への影響，とくに哺乳類や鳥類など高等動物の 污染と影響について紹介する。

\section{地球規模で拡大した污染}

筆者と米国地質調查所の O'Shea 博士は，これまでに 報告された海の哺乳動物の化学物質污染に関する論文を 収集・整理し，検出された化学物質および動物種と個体 数についてまとめた(O'Shea and Tanabe, 1999)。初めて 海棲哺乳動物から有機塩素化合物を検出した論文は 1966 年に発表され，南極のアザラシにDDTとその代謝 物が残留していることを報告した (Sladen et al, 1966; George and Frear, 1966)。しかし，1960年代に海棲哺乳 動物から検出された化学物質は有機塩素化合物 5 種類, 元素 1 種類 $(\mathrm{Hg})$ のみで, 動物も 8 種類 89 検体の鯨類 . 鱪脚類にすぎなかった。ところが，1990 年代では，265 種類の有機污染物質と 50 種類の元素が海棲哺乳動物か ら検出されている。有機污染物質の大半は有機塩素化合 物で, 17 種類の鰖脚類と 40 種類の鯨類を含む総計 5,529 検体でその污染が確認されている。検出された有機塩素 化合物の中には，強毒性の内分泌擋乱物質として関心を 集めているダイオキシンやジベンゾフラン，コプラナ PCB なども含まれている。また，多環芳香族化合物，放 射性核種，有機スズ化合物なども 1990 年代になってそ の残留が報告された。海棲哺乳動物の有害物質活染に関 するこれまでの発表論文数は，18,000 編を越えている。

このように多数の有害物質が膨大な数と種類の海棲哺 乳動物から検出された事実は，化学分析の技術が進歩し たことに加え，この半世紀の間に化学物質の生産や利用 が著しく拡大し，またその環境污染も世界の隅々にまで 拡がったことが背景にある。また最近になって，地球規 模の海洋污染を引き起こしやすい場で有機塩素化合物の 利用が始まったことも要因としてあげられる。工業用材 料や農薬として多用された有機塩素化合物の污染源は陸 上にあり，大気や水を媒体として広域輸送される。かっ てこの種の物質の生産と利用は先進工業国に集中したた め, 北半球中緯度域で最高の污染が認められた。ところ が先進諸国における規制の強化と途上国に扮ける産業活 動の拡大にともない，污染の南北分布は最近変化した。 Fig. 2 に示すように，アジアの沿岸域で二枚貝のイガイ を指標生物にしてモニタリング調査を実施したところ， 有機塩素系農薬 DDTsによる水質污染は, 熱帯・亜熱帯 海域で顕在化していることが判明した。類似の結果は, $\mathrm{HCHs}$ でも認められた。先進国型の化学物質として注目 


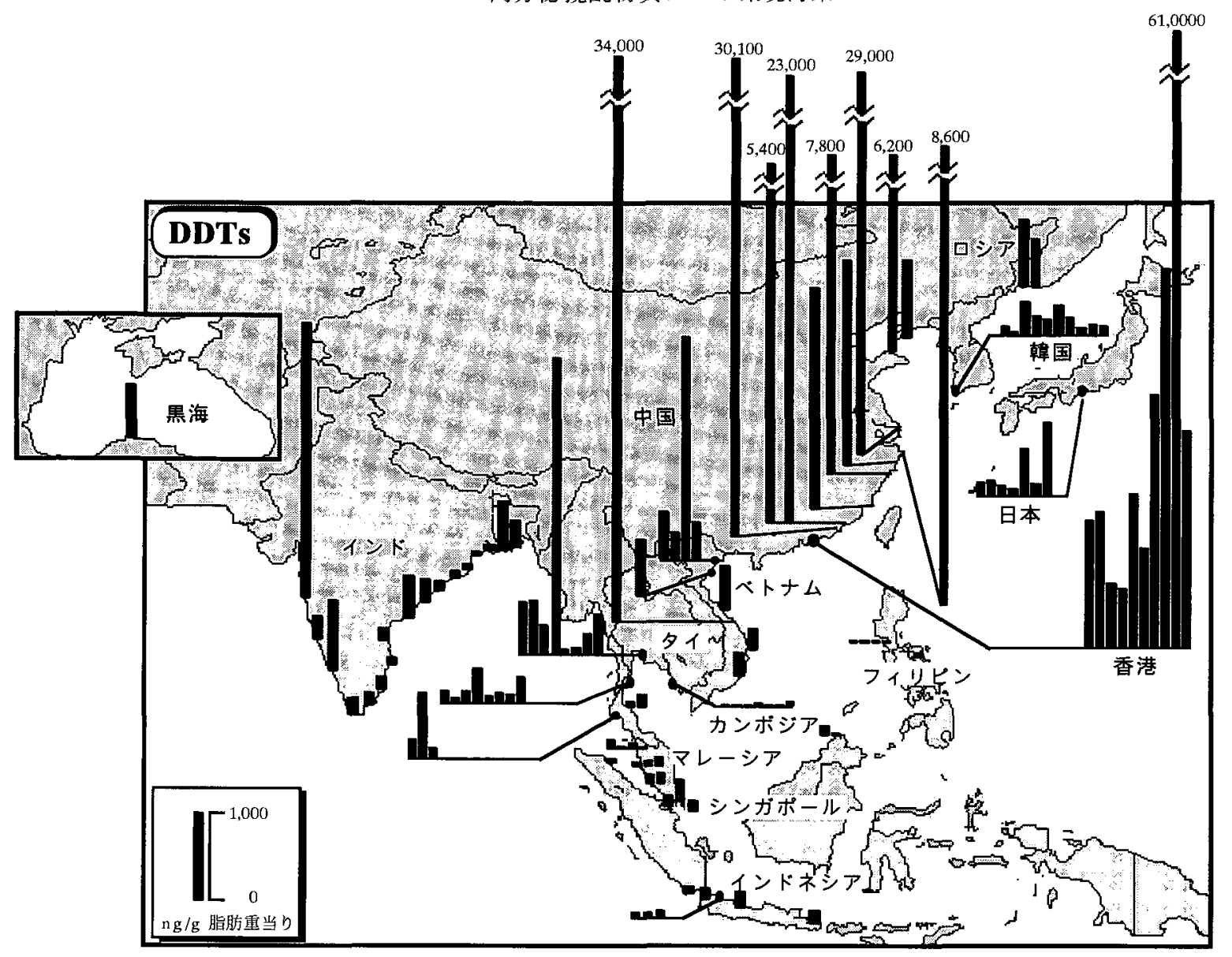

Fig. 2. DDTs distribution in mussels from Asian coastal waters.

図 2. アジア海域に㧍ける二枚具イガイのDDTs 污染.

を集めた PCBs (Fig. 3)やCHLs は中緯度海域の活染が進 んでいるが，その分布は低緯度域にも拡大している (Monirith et al., 2003)。地図を開いてみればわかるよう に，途上国の多くは熱帯・覀熱帯地域にある。南インド の水田地带で有機塩素系殺虫剤 $\mathrm{HCH} の$ 散布試験を行 なったところ, その $90 \%$ 以上はすみやかに大気に揮散 し低緯度地域に招ける化学物質の残留期間は短いことが 判明した (Tanabe et al., 1991)。こうした大気への活発な 揮散は, 熱帯・車熱帯環境の化学物質污染を軽減する効 果はあるが，そこでの無秩序な利用は地球規模の污染に 大きな負荷をもたらすことになる。海洋は地球の面積の 7 割を占めており，熱帯・亜熱帯から放出された化学物 質の大半は世界の海に拡がることになる。つまり, 活染 源の南下は，世界の海洋に分布している海棲哺乳動物に とって最も厄介な場で化学物質の利用がはじまったこと を意味する。有機塩素化合物によるこの種の動物の污染 が顕在化した遠因として, 地球の蒸発皿すなわち熱带. 亜熱带地域における化学物質利用の増大があげられる。

ところで，中低緯度地域で利用された有機塩素化合物
はどのように広がり，最終的にどこに到達するのであろ うか? 残念ながらこうした疑問に応えられる研究は少 ないが，その分布やゆくえを示唆した例はある。有機塩 素化合物による外洋大気扔よび表層海水の活染を地球規 模で調查した例は, 農薬 HCHs の残留濃度が最も高く, とくに北半球の污染が顕在化していることを明らかにし ている (Iwata et al., 1993)。興味深いことに HCHs の高濃 度分布は，この殺虫剤が使用されている熱带・亜熱帯周 辺海域で認められるばかりでなく，北極周辺海域でも観 察されこの傾向は大気よりも表層海水で顕著であった。 対照的にDDTs の残留濃度は全体的に低く，熱帯海域周 辺のみで高濃度分布がみられ，HCHsに比べれば大気に より輸送されにくく污染源周辺にとどまりやすいことが 示唆されている。ところが, PCBsや CHLs は均質な濃度 分布を示し, 南北差も小さいことが明らかにされている。 PCBs CHLs の污染が全世界に広がり一様な分布を示 すことは，依然として中緯度先進諸国からの放出が続い ていることに加え，第三世界を中心に有機塩素化合物の 污染源が今な扰搪大していることを暗示している。西部 


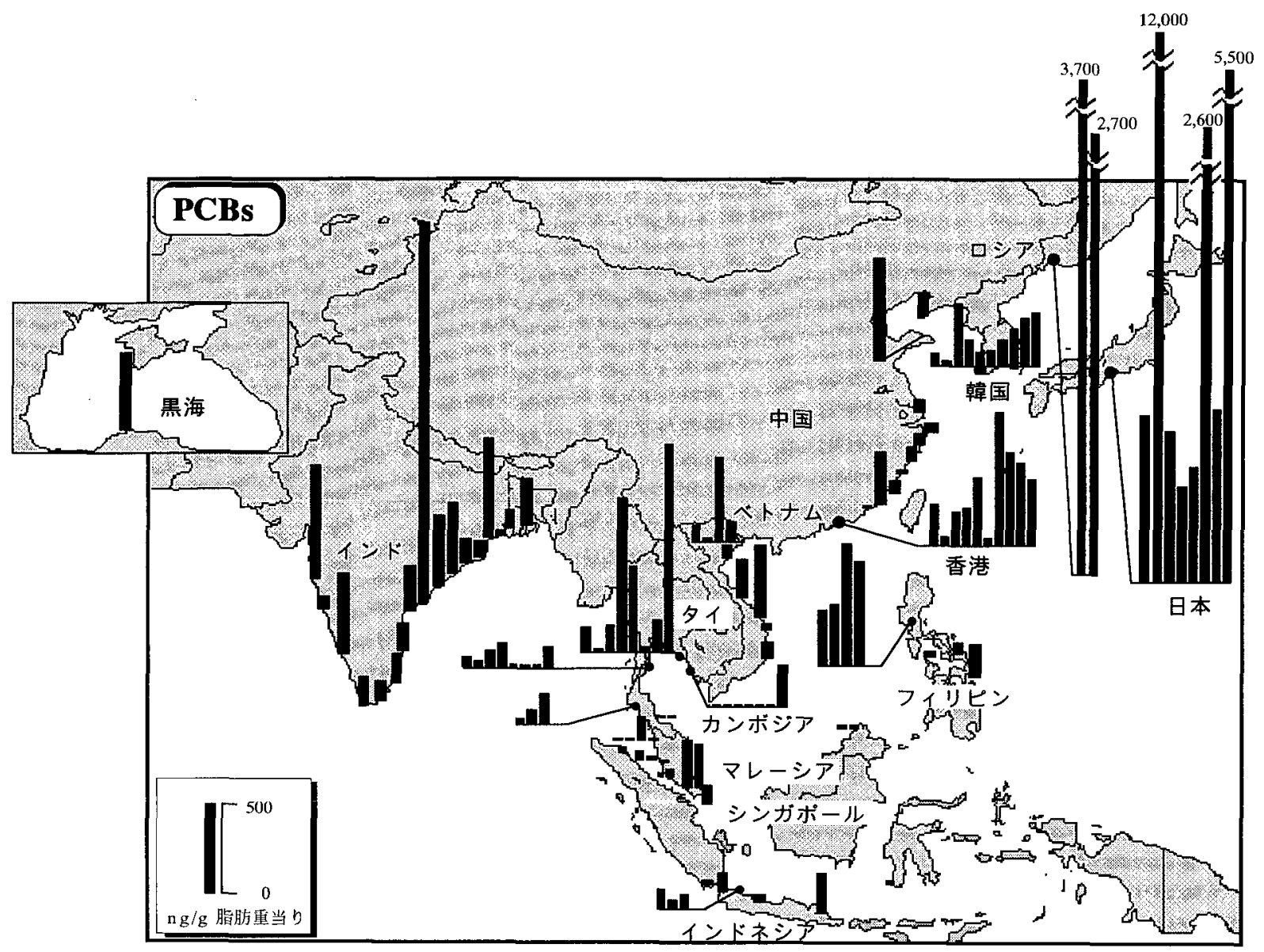

Fig. 3. PCBs distribution in mussels from Asian coastal waters.

図 3.アジア海域における二枚貝イガイの PCBs 污染.

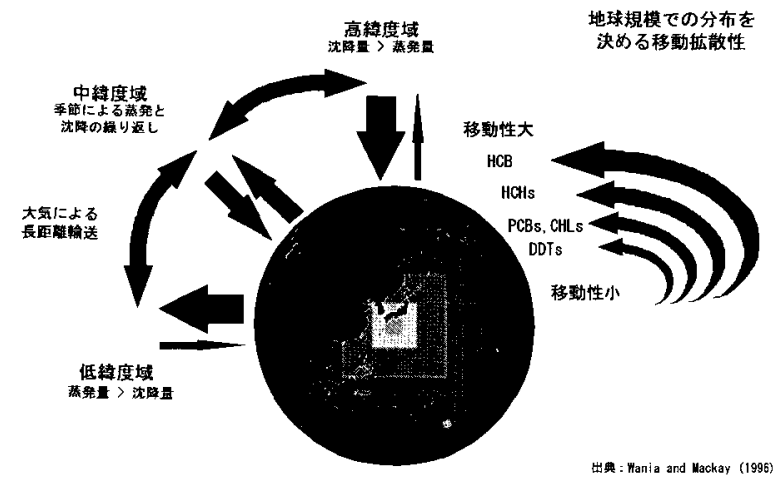

Fig. 4. Schematic representation of the global tranport of organochlorines.

図 4. 有機塩素化合物の移動拡散過程.

北太平洋に棲息するイルカや鯨について有機塩素化合物 濃度を測定した最近の研究は，物質によってその分布に ちがいがあり，外洋表層海水の污染パターンが反映され ていることを明らかにしている(Prudente et al., 1997)。

外洋環境では，有機塩素化合物の污染分布と併せて大
気・海水間での物質交換の研究も行なわれ，その地球規 模でのゆくえが解析されている(Iwata et al., 1993)。大気. 海水間に扮ける有機塩素化合物のフラックス(移動量)を 求めた研究では，ほとんどの海域で負の值が得られてお り大気から海水へ活発に移行していることが明らかにさ れている。HCHsのような農薬の場合，污染源に近い熱 帯海域で大きなフラックスが認められることは当然であ るが，北極のような污染源から離れた海域でも大気から 海水へ活発に流入している。北極域の海水が大きな負の フラックスを示す傾问は PCBsでも認められ，この事実 は外洋の海水がこの種の物質の最終的な到達点として機 能していることを示しており，とくに北極周辺の海水は 有機塩素化合物のたまり場として重要な役割を演じてい ることが推察される(Fig. 4)。このような海洋の特性は 海棲峬乳動物が有害物質のはきだめに生息していること を意味し，この種の動物で多様な有機塩素化合物の蓄積 がみられる一要因でもある。 


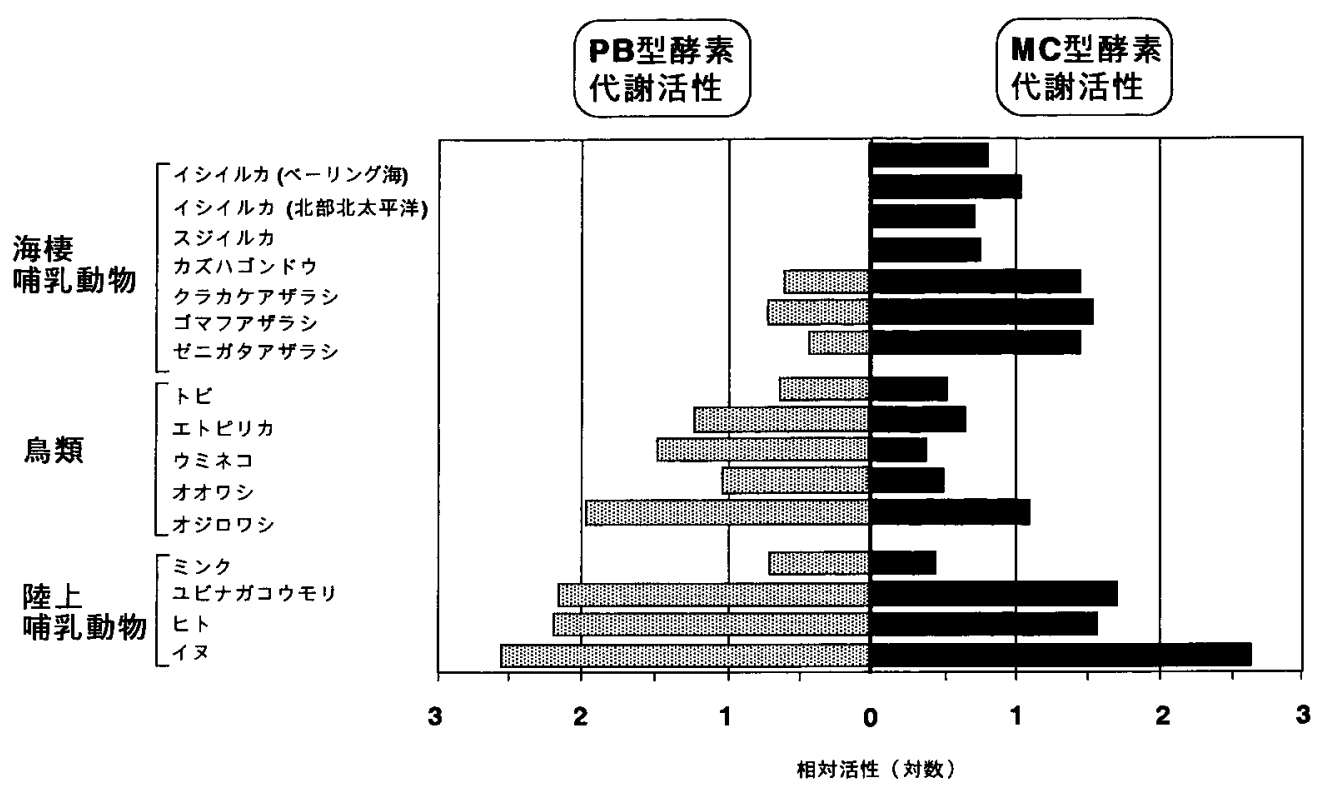

Fig. 5. Relative activity of drug-metabolizing enzyme systems to decompose organochlorines. 図 5. 有機塩素化合物を分解する薬物代謝酵素系の相対活性の動物種間差.

\section{海棲高等動物の特異な生体機能}

海棲哺乳動物の化学物質污染が顕在化しているのは, 污染源の南下や海洋が有害物質のたまり場となっている ことばかりでなく，この種の動物の特異な生体機能も関 与している。

その特異な穖能の第一点は, 海棲哺乳動物の皮下に厚 い脂肪組織があり，ここが有害物質の貯蔵庫として働い ていることである。この脂肪組織はブラバーと呼ばれ， 海棲哺乳動物の種類によって変動するが, アザラシの乳 仔では体重の $50 \%$ を越え，体内の有機塩素化合物のほ とんどがここに残留している。イルカの場合，体重のお よそ $20 \sim 30 \%$ がブラバーで，有機塩素化合物の体内総 負荷量の約 95\% が蓄積している (Tanabe et al., 1981)。 有機塩素化合物は脂溶性が高いため, 一旦脂肪組織に蓄 積すると簡単に出ていかない。したがって，長期間そこ に残留することになる。寿命の長い海棲哺乳動物では, 飭から取り込んだ有害物質が徐々にブラバーに蓄積し, ここが大きな貯蔵場所として働くため高濃度活染に結び ついている。

第二点目は, 海棲哺乳動物の場合, 世代を越えた有害 物質の移行量がばかにならないことである。有害物質が 親から子に移るルートとしては，胎盤を経由する場合と 生後授乳により移行する場合がある。哺乳動物の場合, 一般に胎盤経由での有機塩素化合物の移行量は少なく,
せいぜい母親体内の 5\% 程度であるが，鯨類や鰙脚類の 乳は脂肪含量が高いため, 授乳によって多量の有機塩素 化合物が母親から乳仔に移行する。スジイルカでは，体 内に残留する $\mathrm{PCB}$ 総量のおよそ $60 \%$ が授乳により乳仔 に移行している(Tanabe et al., 1994)。バイカルアザラシ の成熟䧳の場合，授乳によって PCB 执よび DDT 負荷量 の約 $20 \%$ が排泄されている (Nakata et al., 1995)。した がって鯨類や鯺脚類の成熟個体では, 有機塩素化合物の 蓄積濃度に顕著な雌雄差がみられる。このような大量の 有機塩素化合物の母子間移行は，たと之環境の污染濃度 が低下しても，海棲哺乳動物体内の有害物質はそのまま 世代を越えて引き継がれるため簡単に低減しないことを 意味しており，高濃度蓄積や長期污染の一要因となって いる。また，乳仔の体重は母親の10 分の1程度である ため, 有機塩素化合物の体内濃度は授乳期間中に一気に 上昇する。このことは体内蓄積量の問題だけでなく, 毒 性影響も深刻化することを暗示している。

第三点目は，海棲哺乳動物とくにイルカや鯨の仲間は 肝ミクロソームに局在するチトクローム P-450系の薬物 代謝酵素が発達していないため，有害物質をはとんど分 解できないことである。一般に有機塩素化合物を分解方 る薬物代謝酵素系は, フェノバルビタール $(\mathrm{PB})$ 型とメ チルコラントレン $(\mathrm{MC})$ 型に大別されるが, 鯨類は $\mathrm{PB}$ 型の酵素系が久落しており，陸上の哺乳動物や鳥類に比 ベると格段に有害物質の分解能力が劣る(Fig. 5) 


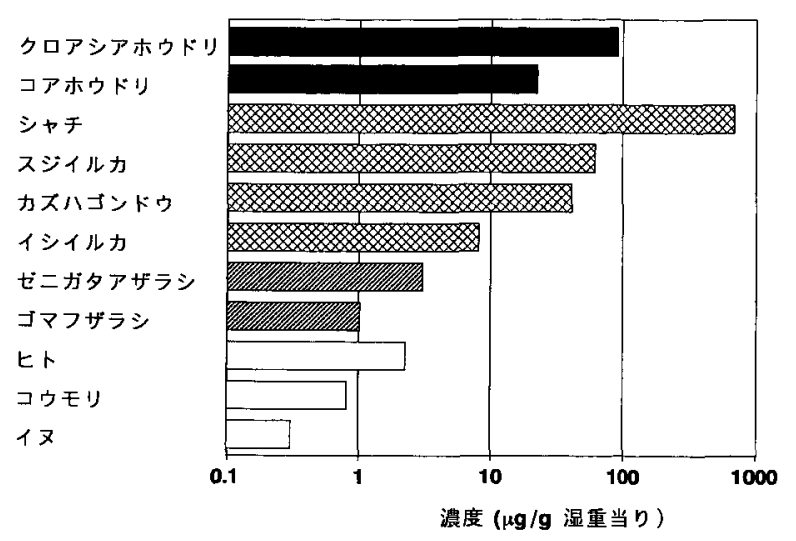

Fig. 6. PCBs concentrations in birds and mammals in Japan and nearby seas and oceans.

図 6. 日本の陸域扔よび周辺海域に棲息する高等動物の PCBs 蓄積濃度.

（Tanabe et al., 1986）。一方アザラシなど沿岸性の鱪脚類 では PB 型および MC 型両方の酵素系が機能している が，陸上の高等動物に比べるとその分解能力は弱い。陸 上, 沿岸, 外洋の方向で高等動物の有害物質分解能力が 低下しているのは, 進化の過程で陸上に比べ海洋の動物 ほど，また沿岸に比べ外洋の動物ほど陸起源の天然の毒 物に曝される機会が少なかったためと推察される。した がって，海棲哺乳動物とくにイルカや鯨の仲間は分解醭 素の機能を発達させる必要がなかったとも考えられ，こ のことが多様な有害物質の蓄積をもたらしたのであろ jo

\section{野生生物の高濃度蓄積}

有害物質の貯蔵庫としての皮下脂肪, 授乳による世代 を越えた移行, 弱い分解能力など, 前述したこれらの要 因はいずれも海棲哺乳動物の高濃度污染に関与するが, とくに注目すべき点は，薬物代謝酵素系の特異性であろ う。高等動物の場合, 酵素系による分解は有害物質の主 要な排泄ルートであり，この機能が未発達であるという ことは飭から取り込んだ多様な毒物が生涯にわたり体内 に残存することになる。そのことを示唆する代表的な事 例として，有機スズ化合物の蓄積があげられる。有機ス ズ化合物の一種であるブチルスズ化合物は，有機塩素化 合物に比べ安定性がそしいため，高等動物の体内では容 易に分解されると考えられていたが，最近の研究により 海棲哺乳動物の肝葴に高濃度で蓄積していることが明ら かにされた(Tanabe, 1999)。また，海棲哺乳動物の中で もとくに薬物代謝酵素系が発達していないイルカや鯨
は,有機塩素化合物を驚くほどの高濃度で蓄積している。 たとえば西部北大平洋のスジイルカは，海水中の一千万 倍もの高濃度でPCBを蓄積している (Tanabe et al., 1984)。異常な蓄積はこれだけではない。一般に化学物 質の濃度は，陸上の污染源から遠ざかるにつれて低減す るのが普通であるが，本来清浄なはずの外洋に棲息して いるイルカや鯨は, 陸上や沿岸の高等動物よりはるかに 高い濃度でPCBを蓄積している (Fig. 6)（Tanabe et al., 1994)。外洋性の動物が高涉度の有機塩素化合物を蓄積 している他の事例として，アホウドリがある (Jones et al., 1996; Guruge et al., 2001)。興味深いことに, 北太平洋の クロアシアホゥドリでは, 一部の検体から約 $100 \mathrm{ppm}$ の PCBs が検出されており (Fig. 6), DDTs の残留濃度も きわめて高い。イルカや鯨と同じように，外洋を主な棲 息域としているアホウドリ類も，チトクロームP-450系 の薬物代謝酵素が一部欠落しているものと予想される。

イルカや鯨, アザラシなどの海棲哺乳動物は, ダイオ キシン類の蓄積濃度も高い。とくに, コプラナPCBの 污染が顕在化しており，このことは最近の環境庁の調査 でも明らかにされている(田辺，2002a）。海棲哺乳動物 や魚食性の鳥類は, 数千 $\mathrm{pg} \mathrm{TEQ} / \mathrm{g}$ (脂肪重当り)の濃度 を示すものがかなりあり，この值はヒトから検出された ダイオキシン類の蓄積濃度をはるかに上回る(Fig. 7)。 弱い薬物代謝機能をもつなど，ある種の野生生物にはヒ トとは違う生理機能があり，そのことが内分泌摚乱物質 の蓄積濃度や毒性影響に関与していることが考えられ る。

\section{毒性影響}

有機塩素化合物による海洋污染が注目されはじめた きっかけは，その毒性影響が高等動物にあらわれている という示唆であろう。イギリスの生態学者 Simmonds は, 記録として残されている海棲哺乳動物の大量変死事件が 20 世紀になって 11 件あることを報告しているが，この うちの 9 件は 1970 年以降に集中している (Simmonds, 1991）。しかも大量変死事件のほとんどは先進工業国の 沿岸域で発生しており，このことはこうした異常が物質 文明の進展と無縁ではないことを包わせている。また “Our Stolen Future (邦訳「奪われし未来」, 翔泳社)”の著 者 Colborn は, 海棲哺乳動物の異常(個体数の減少, 内 分泌系の疾病，免疫機能の失調や腫瘍など)総説とし てまとめ，1968 年以降 65 例にのぼる報告があり，その 原因として生物蓄積性の内分泌擋乱物質すなわち有機塩 


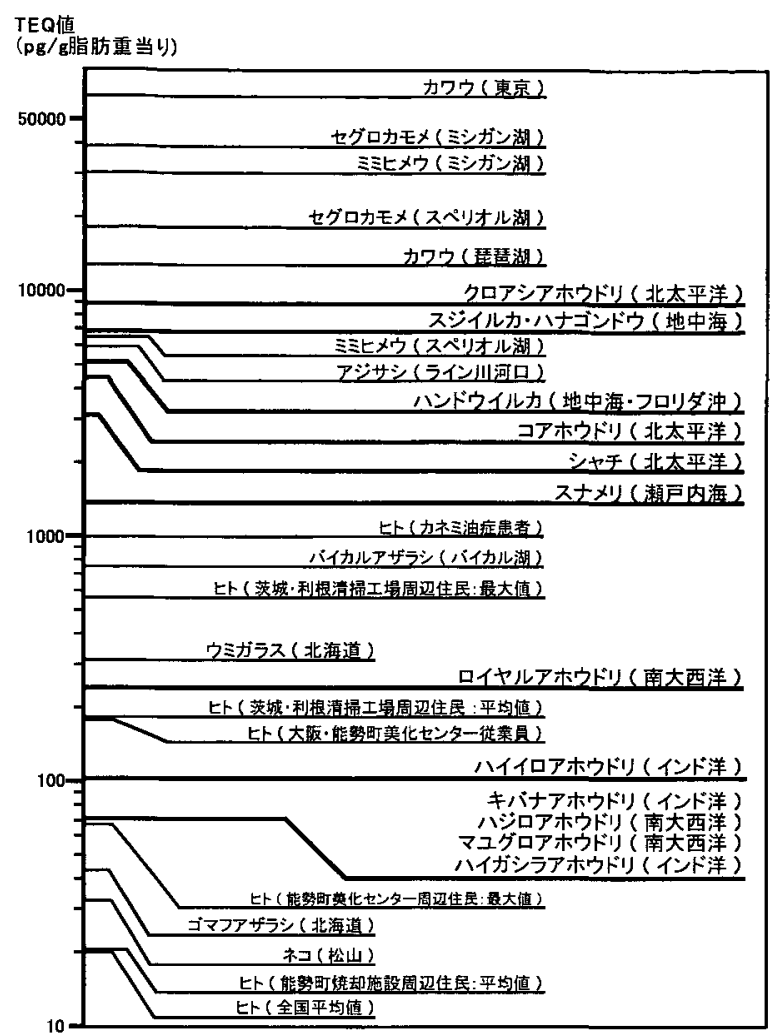

Fig. 7. Comparison of TEQ concentrations of PCDDs and related compounds in higher wildlife and human.

図 7. 野生高等動物およびヒトから検出されたダ イオキシン類の TEQ 濃度.

素化合物が関与していることを示唆している (Colborn and Smolen, 1996)。

環境ホルモンの毒作用機序は，ホルモンレセプターと 結合し，ホルモン擬似の作用を介して内分泌系を擋乱す ると説明されているが，環境污染物質によって誘導され る薬物代謝酵素系もホルモンを摚乱する。有害物質が蓄 積すると, 肝臓のチトクローム P-450酸化酵素系が誘導 され，この酵素系が化学物質を活性化してガンや奇形を 引き起こしたり，ステロイドホルモンを代謝し生殖機能 を摚乱する。また，胸腺に作用して，免疫機能の失調を もたらすこともある。したがって野生の高等動物では， 化学物質の蓄積量, 薬物代謝酵素の活性やホルモンの濃 度，病的症状の三者の関係を明らかにし，有害な影響を 検証する研究が求められている。しかし, この種の研究 ははじまったばかりであり，情報は大幅に久落している が，有機塩素化合物の影響を匂わせる結果がないわけで はない。例えば，北部北太平洋の冷水域に生息するイシ イルカでは, PCB および DDE (DDTの安定代謝物)の残
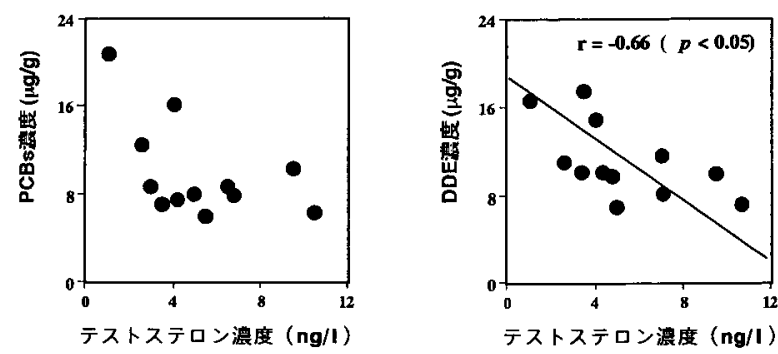

Fig. 8. Relationship between PCBs/DDE concentrations in the blubber and testosterone levels in serum in adult male Dall' porpoises from northern North Pacific.

図 8. 北太平洋で捕獲されたイシイルカ成熟雄の脂皮に 残留する PCBs 拉よびDDE 濃度と血清中テスト ステロン濃度の関係.

留濃度と雄の性ホルモン・テストステロン濃度との間に 負の関係が認められ，この種の物質の濃度が高いとテス トステロンの濃度は低いという傾向がみられる(Fig. 8) (Subramanian et al., 1987)。また，三陸沖の才ットセイ調 查では，PCB の残留濃度と薬物代謝酵素活性の間に明 瞭な正の相関がみられている(Tanabe et al., 1994)。さら に飼育下のキタゾウアザラシ (Lahvis et al., 1995)や米国 フロリダ沿岸の野生バンドウイルカ（Shaw, 1998)では, 低濃度の有機塩素化合物でリンパ球の増殖活性が阻害さ れることが報告されている。因果関係を裹付ける知見の 集積は今後の課題であるが，こうした結果は，現実の有 機塩素化合物蓄積濃度で薬物代謝酵素系が誘導されたり ホルモンレセプターとの結合や免疫機能の抑制がおこっ ていることを窺わせ，内分泌系や免疫系の擋乱など化学 物質の長期的 - 慢性的な毒性影響が，野生の海棲哺乳動 物で起こりうることを暗示している。

\section{污染と影響の将来}

有機塩素化合物の長期的な影響を予測するには，污染 の消長を理解することが必要となる。この場合, 保存試 料を用いて過去の污染を復元し将来を予測することが望 ましいが，海棲哺乳動物や鳥類の場合，有用な試料は少 ない。断片的ではあるが，三陸沖で捕獲したオットセイ の保存試料では，1970年代の中頃 PCB やDDT 污染の 極大がみられ，その後濃度は低減したが 1980 年代以降 の PCB 污染は定常状態を示し, HCH の活染には明瞭な 低減傾向が認められていない(Tanabe et al., 1994)。南氷 洋で捕獲したミンククジラの調査では, 最近 10 年間有 機塩素化合物の濃度はほとんど变化しておらず PCB は むしろ増大傾向にあることが判明している（Fig.9） 


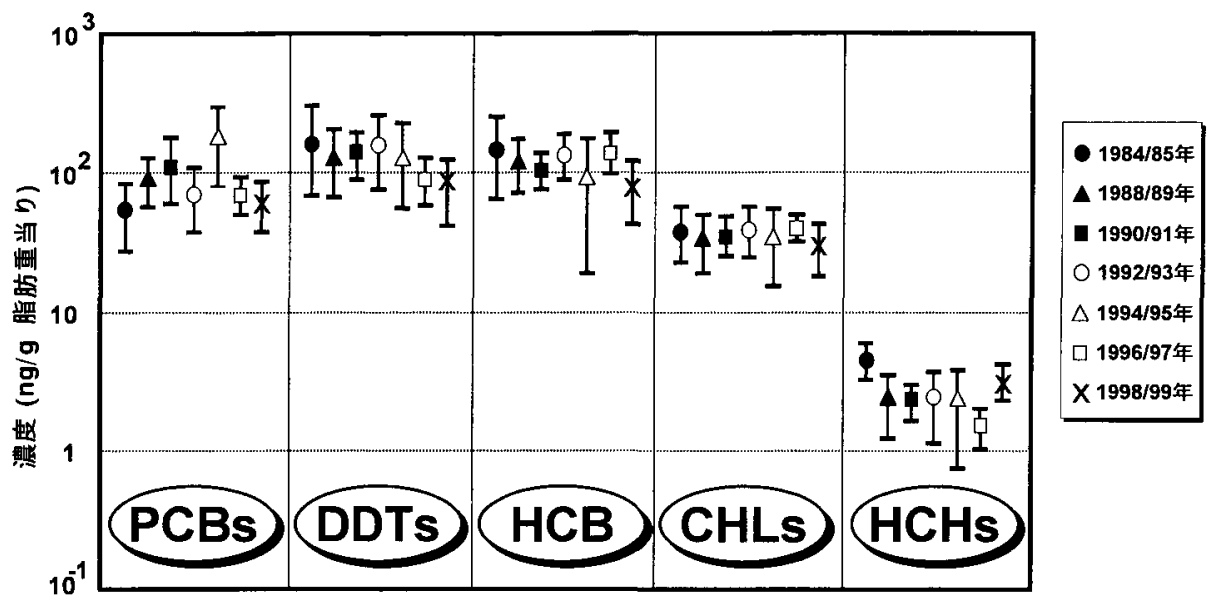

Fig.9. Temporal trends of persistent organochlorine concentrations in the blubber of minke whales from Antarctic Ocean.

図 9. 南水洋産ミンククジラの脂皮から検出された有機塩素化合物 濃度の経年的推移.

(Aono et al., 1997)。こうした過去の污染の復元は，海凄 哺乳動物に㧍ける有機塩素化合物の暴露と影響が, 今後 しばらく続くことを暗示している。とくにPCBによる 污染とその毒性影響は深刻で，モニタリング調查の継続 が望まれる。

\section{途上国の POPs 問題}

POPs とは, 残留性有機污染物質 (Persistent Organic Pollutants)の略称で，環境中に長期間残存する，大気や 水を媒体として地球規模で越境移動する,生体内に濃縮・ 蓄積し健康被害をもたらす可能性がある物質と定義され ている。現在のところ, 意図的生成物質として PCBs, DDT, クロルデン, トキサフェン，アルドリン，ディ ルドリン，エンドリン，ヘプタクロル，マイレックスの 9 種類, 非意図的生成物質としてダイオキシン，ジベン ゾフラン, ヘキサクロロベンゼンの 3 種類, 合計 12 物 質が対象となっている。これらはいずれも有機塩素化合 物で, この種の物質による地球規模での環境污染とヒ卜 や野生生物に対する影響がきわめて深刻化し，そのこと が国際社会で認知され污染防止対策を強化する必要に迫 られたため, 条約締結の議論が開始された。ほとんどの 先准諸国ではすでにPOPsの生産を禁止しているが，一 部の途上国や旧社会主義国での使用が続いているため, その環境污染は今なお進行しており，依然として高い学 術的・社会的関心を集めている。したがって, POPs 問題 の本質は, 先進国だけでなく第三世界にもあるといえる。
POPs 条約が締結されると，有機塩素化合物の環境污 染レベル，あるいは生態系の濃度レベルは低減すること が期待される。先進国だけでなくて途上国でも条約締結 の効果はあらわれると考えられる。しかし，非意図的生 成物質であるダイオキシン類の污染は，今後途上国で進 行する怖れがある。その一端として，途上国のゴミ問題 に电来するダイオキシン類の二次生成があげられる。

ダイオキシン類は，環境残留性や生物蓄積性が高く, また強毒性のため，先進諸国を中心に，これまで多くの 污染実態調查やリスク評価が実施されてきた。その結果 先進諸国では，焼却施設の改善や化学物質の流通・使用 規制強化の効果があらわれ，大気，水，土壤，生物など さまざまな環境試料のダイオキシン類濃度に低隇傾向が みられている。一方, 近年急速な経済発展が谁み，人口 増加の著しいアジアの途上国では，日々多くの廃棄物が 都市ゴミ集積場に投棄され，自然発火や意図的焼却によ り低温で然焼している。このことから，アジア途上国の ゴミ集積場では，燃焼に伴うダイオキシン類の生成が予 想され，周辺環境への污染の拡大も顝念される。加えて, これらゴミ集積場では，機器類，プラスチック，金属製 品, 紙類, そして生ゴミといった多様な廃棄物が分別さ れることなく投棄されていることから，トランスやコン デンサーに使用された PCBs，機器類や金属製品に含ま れる微量元素など，多様な有害物質による污染も考元ら れる。また，疫病を媒介する病害虫の発生を防止するた め, 殺虫剤等も散布されており, その污染と影響も危惧 される。 
しかしながら，途上国のゴミ集積場では，これら有害 物質の污染調查はほとんど行われておらず，ヒトの曝露 影響を評価した研究もみあたらない。ゴミ集積場周辺に は多くの住民が居住しているだけでなく，大人に加え多 数の子どもが waste-pickerとして場内で労働しているこ とから, 若い世代も有害物質の曝露を受けている。感受 性の高い胎児期や乳児期にお㤝有害物質の曝露は, 免 疫機能や脳の発達に影響を及ぼすことが示唆されてお り,ゴミ集積場では疫学的な調査の実施も望まれている。 そこで，アジア途上国の都市ゴミ集積場抢よびその他地 域で採取した土壤のダイオキシン類, 母乳のダイオキシ ン類抢よびその他の有機塩素化合物について，その污染 実態を調査した(田辺，2002b)。

その結果，アジア途上国の都市ゴミ集積場内抢よびそ の周辺で採取した土壤試料すべてから，ダイオキシン類 が検出された(Fig. 10)。カンボジアとインドのゴミ集積 場内のダイオキシン類濃度は，周辺土壤より明らかな高 值を示し，ゴミの自然発火や意図的焼却によるダイオキ シン類の生成および PCB を含む廃亲物からのコプラ ナーPCBsの漏洩が示唆された。アジア途上国の都市ゴ ミ集積場内の土壤と先進諸国の焼却施設周辺, 都市・工 業地域, 農業地域の土㙥中ダイオキシン類濃度を比較し たところ，ほほ同等の高い值が認められ，途上国都市ゴ ミ集積場に先進諸国に匹敵するダイオキシン類污染源の あることが判明した。とくに，カンボジアの集積場内の 3 地点では，日本の環境基準値 $1000 \mathrm{pg}-\mathrm{TEQs} / \mathrm{g}$ を超え る高濃度のダイオキシン類が検出された。

さらにダイオキシン類はヒトの母乳試料でも検出さ れ，途上国のゴミ集積場周辺住民は，ダイオキシン類の 曝露を受けていることが明らかとなった(Fig. 11)。ゴミ 集積場周辺住民の PCDD/DFs 濃度はインド>フィリピ ンミベトナムミカンボジアの順であり，インドのゴミ集 積場周辺住民は，対照地域住民と比べても明らかな高値 を示した。このことは，インドのゴミ集積場にダイオキ シン類の発生源が存在し，その影響が周辺住民に及んで いることを示唆している。先進諸国の場合, ヒトのダイ オキシン類曝露は, 魚, 畜肉, 卵, 乳製品などの動物性 食品経由が $98 \%$ 以上を占め，大気からはわずか $1.1 \%$ と推定されている。インドのゴミ集積場内には牛などの 家音が飼育されており，周辺住民はこれら牛のミルクを 飲用している。このことから，インドのゴミ集積場周辺 住民は，場内で発生したダイオキシン類によって污染さ れた食品を通して曝露を受けた可能性がある。一方，高 濃度の土穓励染がみられたカンボジアやフィリピンのゴ

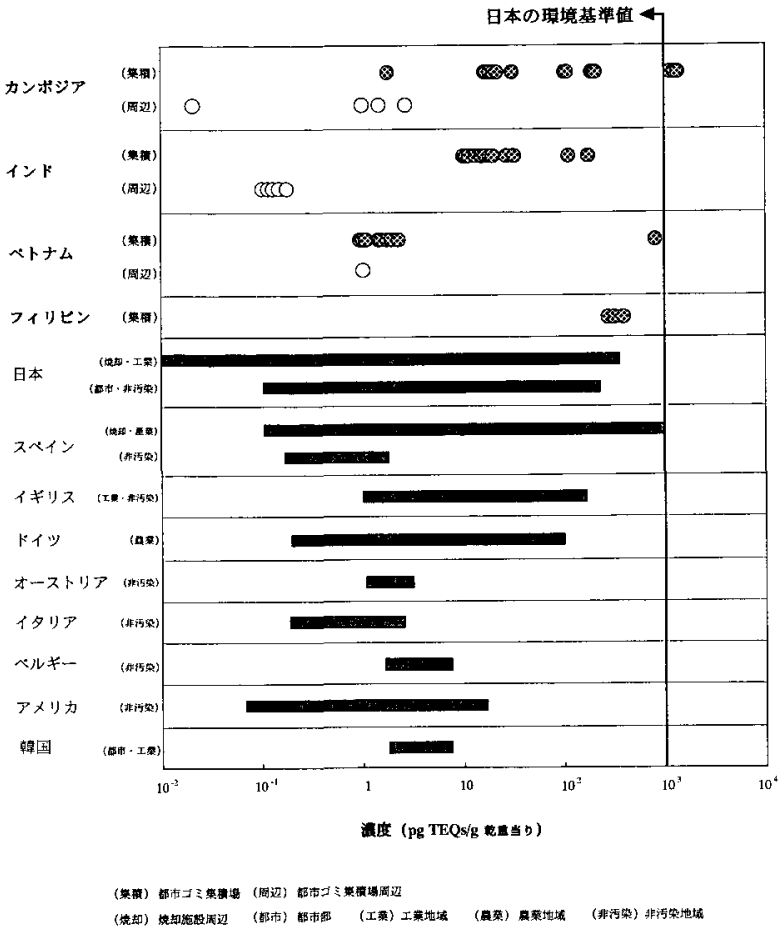

Fig. 10. Comparison of PCDDs and related compounds concentrations in soils from dumping sites of municipal wastes in Asian developing countries and those in various pollution source areas in developed nations.

図 10.アジア途上国のゴミ集積場内とその周辺から採 取した土潩中のダイオキシン類漂度と先進諸国 の污染レベルとの比較.

ミ集積場内には家音などの動物は飼育されておらず，周 辺住民がダイオキシン類で污染された食物を摂取してい る可能性は低いと考えられる。

アジア途上国の都市ゴミ集積場周辺住民がら採取した 母乳のダイオキシン類濃度を，他の国で報告されている 一般人のデータと比較したところ (Fig. 11)，インドの都 市ゴミ集積場周辺住民の母乳から検出されたダイオキシ ン類濃度は，世界的にみても高值であり，日本や欧米の 一般人と同等，もしくはそれ以上のレベルを示した。一 方, ベトナム, フィリピン, そしてカンボジア住民の濃 度レベルは, 先進諸国の一般人に比べると低く, 他の途 上国の住民と同程度であった。インドの母乳の TEQs 濃 度が先進諸国に匹敵するレベルであったことは，注目す ベき結果である。ベトナムの枯葉剂や台湾の油症事件を 除けば，これまでダイオキシン類の污染は先進国の問題 だと言われてきた。しかしここに示した結果は，途上国 にもゴミ集積場のようなダイオキシン類の大きな発生源 があり，それが土壌やヒトの活染をもたらしていること， 


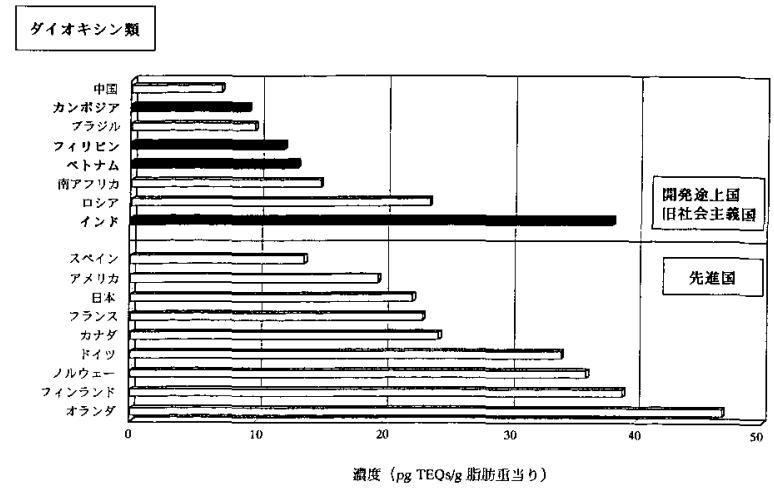

Fig. 11. Comparison of concentrations of PCDDs and related compounds in human breast milk from dumping sites of municipal wastes in Asian developing countries and those from other countries.

図 11.アジア途上国のゴミ集積場内から採取した母乳 および他地域住民の母乳中ダイオキシン類濃の 比較. 黑棒は著者らの分析結果, 白棒は文献值.

つまり途上国にもダイオキシン問題は存在することを明 確に示している。日本や欧米の先進国では, 母乳のダイ オキシン類レベルは減少傾向にある。これら先進国では, 高性能焼却施設の普及·改良や化学物質の流通・使用規 制強化の効果があらわれているものと考えられる。一方， アジアの途上国のように，現在まったく排出源対策がな されていない地域では今後さらにダイオキシン類による 污染が進行し，母乳の濃度レベルが上昇することもあり 得る。

ところで,アジアの途上国ではダイオキシン類以外の 有機塩素化合物による母乳污染も梁刻化している。Fig. 12 に示すように，インドの住民から採取した母乳は HCHs の污染が顕著で，他の途上国住民より1〜2桁高 い値を示した。インドでは，野生生物の調查でも高濃度 の $\mathrm{HCHs}$ が検出されており，今なおこの薬剂を使用して いることが推察される。カンボジア住民の母乳は DDTs 濃度が最も高く，他の有機塩素化合物より1桁高い值で 検出された。その DDTs 濃度は, ベトナム住民の平均値 より低值であったが，他のアジア途上国掞よび先進国の 日本より高い值を示した。カンボジアでは魯類の寄生虫 駆除にDDTが使用されており，魚介類の污染実態調查 でも高い DDTs 濃度が検出されている。カンボジア住民 の高いDDTs 母乳レベルは，公衆衛生目的で使用された DDT の曝露に加え，魚介類からの取り迟みも考えられ る。ベトナム住民の母乳はDDTs 污染が進行して抢り， 日本や他のアジア途上国と比較すると明らかに高いレベ ルがみられた。べトナムの DDTs 污染が顕在化している
ことは, 1980 年代に実施された母乳㱙染調查や最近の 食品污染実態調查でも指摘されており，マラリア対策な ど公衆衛生を目的とした使用がその主な原因と考えられ る。またべトナムでは PCBs 濃度も, 日本人より低值で はあるが，他のアジア途上国に比べると高い值が認めら れた。污染源は不明であるが，べトナム戦争当時旧ソ連 や欧米から持ち込まれた兵器, 軍用機, 戦闘車輛, 電気 機器などに使用された PCBs の漏出が疑われる。フィリ ピン住民の母乳の有機塩素化合物残留レベルは全体的に 低值であったが，DDTs 濃度は相対的に高く，ついで PCBs, CHLs, HCHs, HCB の順で検出された。1970 年 代以降フィリピン政府は，DDTや $\mathrm{HCH}$ 等有機塩素系農 薬の生産, 使用, 輸入, 販売を厳しく規制したため, 母 乳中の有機塩素化合物濃度は低值を示したものと考えら れる。

先進国と第三世界の母乳污染を比較すると, 殺虫剤の DDTs やHCHs による污染は明らかに途上国や旧社会主 義国住民の濃度が高く，PCBsは先進諸国住民の污染が 顕在化しているが，旧社会主義国の一部で先進国に匹敵 するPCBs 污染が認为られることは興味深い(Fig. 12)。 アジア地域の母乳污染パターンは, 先に示した二枚貝イ ガイの污染分布 (Fig.2，Fig. 3) と類似して抢り，こうし た知見をふまえた包括的な POPs 污染防止対策の展開が 望まれる。

母乳の有機塩素化合物濃度は, 母親の年齢, 出産回数, 授乳期間, 栄養状態など, 様々な要因によって变動する。 アジア途上国の住民について，母乳のダイオキシン類お よび有機塩素化合物濃度と母親の出産回数の関倸を調べ たところ, 出産回数が多い母親の母乳ほど有機塭素化合 物濃度は低い傾向がみられた(Fig. 13)。脂溶性が高い有 機塩素化合物は，体内の脂肪組織から母乳の脂肪へ移行 して体外へ排泄されるため, 出産を重ねる度に母乳の濃 度は減少していくものと考えられる。このことは，母乳 を介した第一子への污染物質の移行量は，第二子以降よ り相対的に多いことを意味しており，第一子に対する毒 性上のリスクも大きいことを暗示している。

上記の結果は, 少子化の問題と関連づけて考える必要 がある。たとえば，先進国では女性の出産率が低下し， わが国の場合現在平均 1.33 人でしかも高齢出産の傾向 にある。中国では 1 人っ子政策が推進されているが，こ れが近年中に法制化される。そうすると先進国や中国で は第 1 子が増えることになり，環境ホルモンによる乳児 の污染とそのリスクは相対的に高くなると予想される。 このことは乳幼児の健康や知能の発達に影響を及ばすだ 


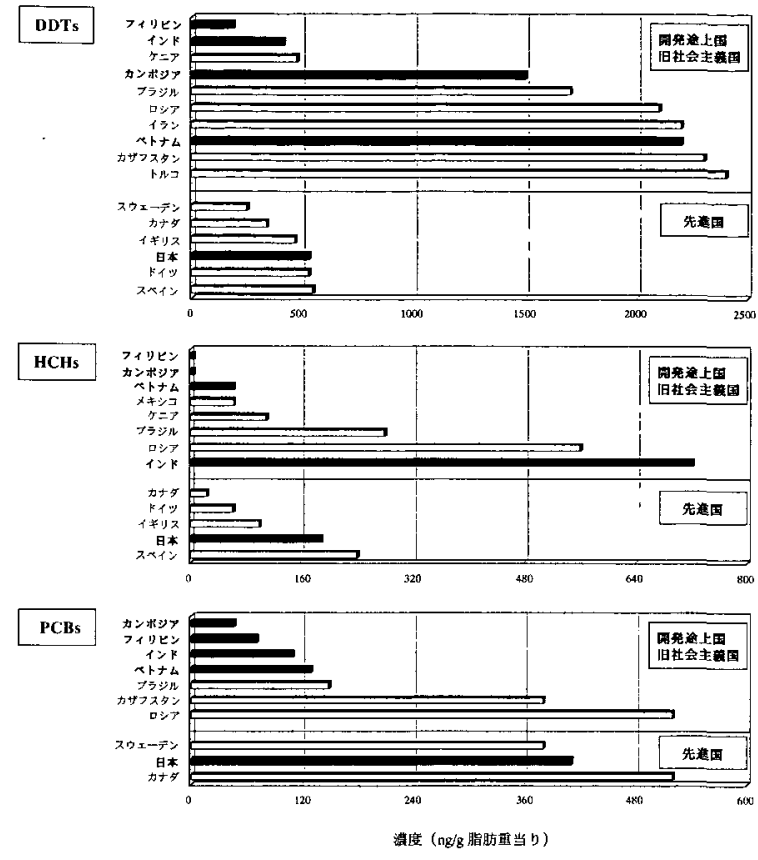

Fig. 12. Comparison of DDTs, HCHs and PCBs concentrations in human breast milk from dumping sites of municipal wastes in Asian developing countries and those from other countries.

図 12.アジア途上国住民と他の途上国および先進諸国 住民の母乳中有機塭素化合物濃の比較。黑棒は 著者らの分析結果, 白棒は文献值.

けでなく，国民全体の厚生や知的水準の推移等にも係わ る可能性があり，こうした観点の対策も今㣪検討する必 要がある。

ところで，体重 $5 \mathrm{~kg}$ の乳児は毎日䄪 $700 \mathrm{ml}$ の母乳を 授乳する。この数値と母乳から検出された有機塩素化合 物の濃度をもとに, 途上国の乳幼览が母乳を通して摂取 する1日当たりの有機塩素化合物量を見積もり, WHO (世界保健機構)や Health Canada(カナダ保健省)が定め る安全基準值 (TDI) と比較した (Fig. 14)。その結果, 最 も高いダイオキシン類掑取量が得られたのはインド住民 の母乳で，カンボジア， ベトナム，フィリピンを含むほ とんどの母乳において, WHO が定める TDI の $4 \mathrm{pg}$ TEQs $/ \mathrm{kg}$ /日を超えた。また, HCHs と DDTs の損取量は一部 住民の母乳のみ TDI を越えたが，インド住民の母乳中 $\mathrm{HCH}$ に関しては，TDI 上回る試料が多数存在した。以 上の結果から，途上国住民の母乳に含まれる有機塩素化 合物は，乳児に対する健康影響が懸念されるレベルにあ る考えられた。

乳児の健康を考えた場合，有機塩素化合物で污染され ていない人工乳を利用することは，そのリスクを軽減す

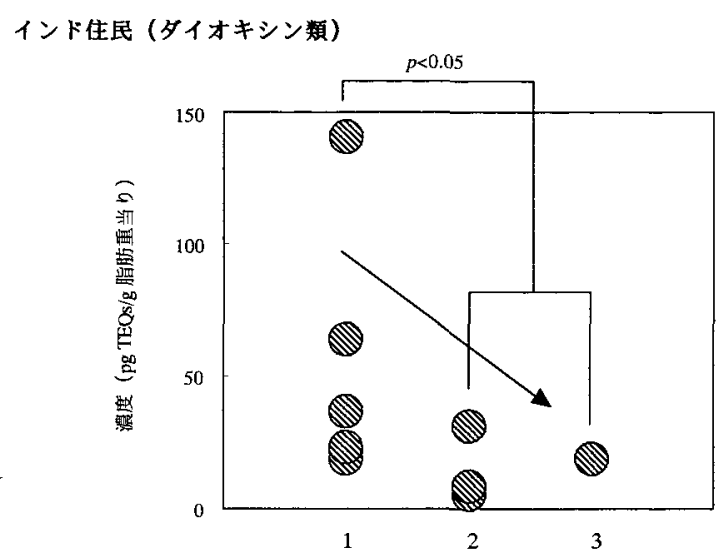

ベトナム住民（DDTs）

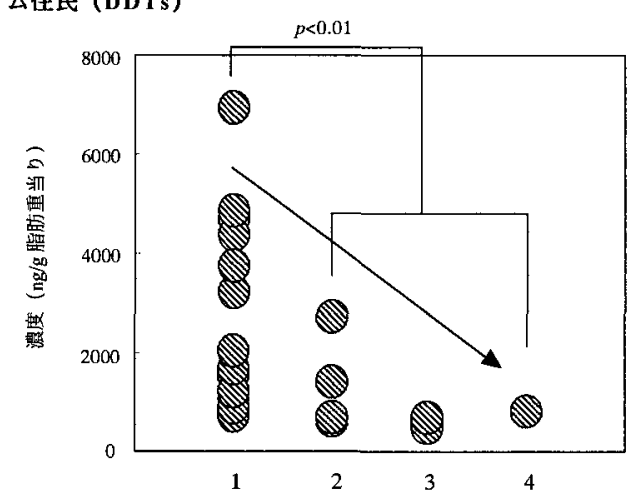

カンボジア住民 (DDTs)

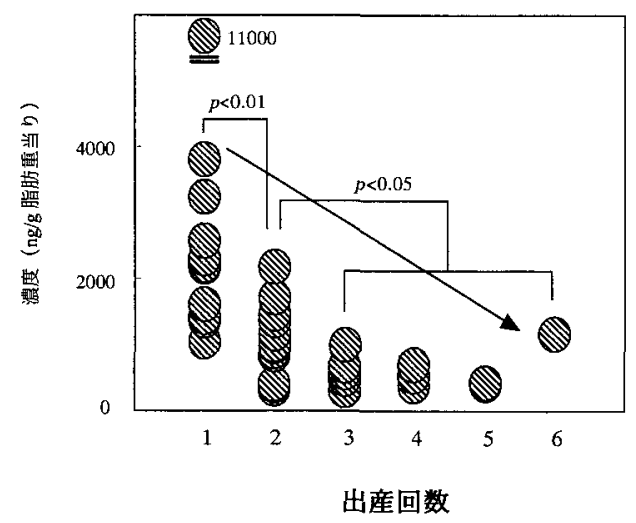

Fig. 13. Relationship between concentrations of DDTs, PCDDs and related compounds in human breast milk from Asan developing countries and the parturitional history of mother.

図 13、母乳中のダイオキシン類执よびDDTs 濃度と 母親の出産回数の関係.

る1つの方法である。しかし，母乳には栄養素だけでな く，乳児の免疫システムを支える IgA 抗体や糖タンパ クであるミルクムチン, バクテリアやウイルスの活性を 抑制するオリゴ糖，ラクトフェリン，リソチームなど乳 

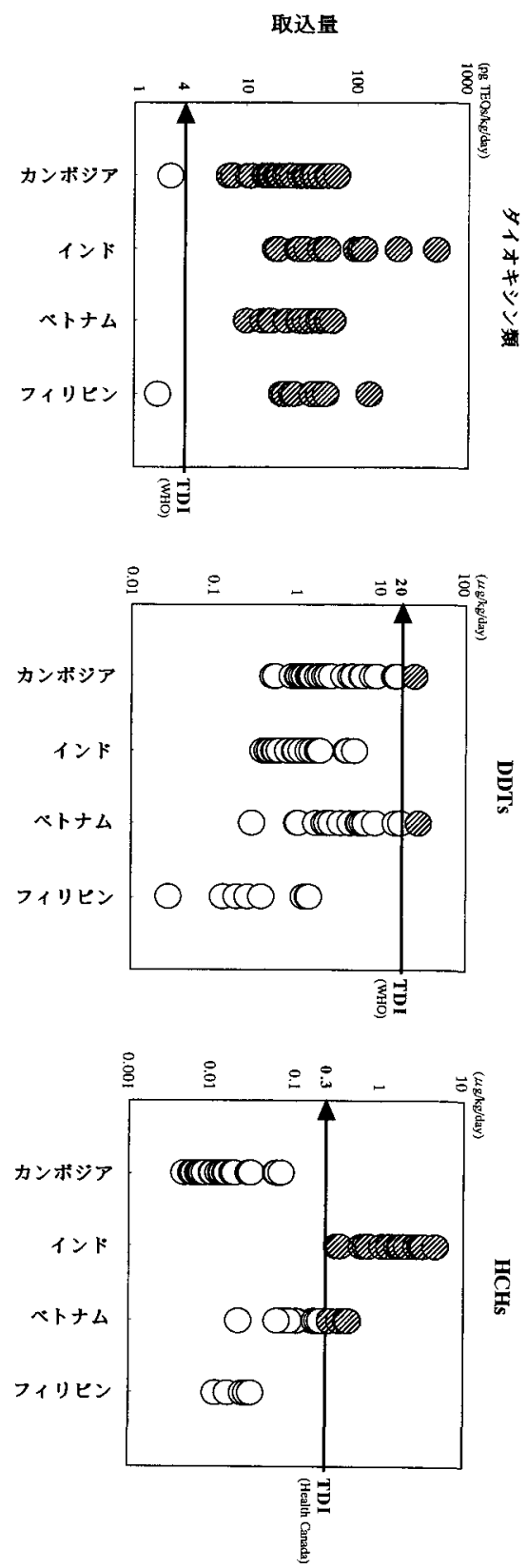

Fig. 14. Comparison of daily intake of persistent organochlorines through lactation in infant of Asian developing countries and those tolerable daily intake (TDI) for human health.

図 14.アジア途上国乳児が授乳により攝取 する有機塩素化合物量と安全基準值 (TDI)の比較.

児の発育や成辰に必要な成分が含まれている。また，母 乳に含まれる長鎖不飽和脂肪酸は脳の発達に不可欠であ ク，母乳で生育した子どもは，人工乳を与えられた子供 より知能が高いことを示唆したデー夕もある。これら成
分の量的・複合的効能は十分解明されていないが，母乳 量の不足は乳愳の健全な生育に何らかの影響を及ぼす可 能性がある。さらに，先進国の人工乳は栄盖成分が豊富 で安全性の高いものが供給されているが，途上国の場合 は栄養成分の不足や安全性に問題があるだけでなく，使 用する水も乳巟に悪影響を及ぼすことがある。これらの ことを併せて考えると，途上国では乳児に母乳を与える ことが不可欠と思われ，そのためには母乳中の有機塩素 化合物濃度を低減する努力が必要である。しかし，母乳 中の有機塩素化合物濃度は, 食事よりも母親の脂肪組織 からの流動の方が笴与率が高いため, 低濃度の食品を選 択するなど短期間の努力では湱度の低減は期待できな い。母乳中の有機塩素化合物濃度を安全なレベルまで下 げるには，早い時期から母親体内の曝露量を減らすこと が肝要なため，アジアの途上国では早急に活染対策を検 討する必要がある。

\section{おわりに}

以上のべたように，野生の高等動物には，ヒトではみ られない特異な污染や生理機能があり，このことはヒト 中心の環境観では生態系は守れないことを教えている。 鯨や鳥の化学物質污染がヒトとは無縁であるとする考え 方は，もはや地球環境時代に馿染まない。「野生生物で みられる化学物質の污染と影響は, ヒトへの警鐘であ る」すすなわち化学物質のリスクから生態系を守ること はヒトに対する安全性の確保にも慗がるという基本理念 を育て，生態系本位の環境観を社会に定着させることが 今後の大きな課題であろう。将来人間の健康に影響を及 ぼす可能性がある問題として，野生生物の污染や異常を 考える必要がある。

また，先進国だけでなく途上国でも環境ホルモン污染 は顕在化しており，今後さらに深刻化することが予想さ れるため, 地球環境問題の重要課題と位置づけPOPs 条 約の締結等国際対応をすすめる必要がある。途上国の環 境ホルモン問題を解決するには，先進国の国際協力や支 援が不可欠であり，アジア地域に打いてわが国の国際貢 献が問わ扎ることはいうまでもない。

\section{文献}

Anderson, E. (1993): Developing nation's chemical exports surge. Chemical and Engineering News, Aug. 2: 14-15.

Aono, S., S. Tanabe, Y. Fujise, H. Kato and R. Tatsukawa ( 1997 ): Persistent organochlorines in minke whale 
(Balaenoptera acutrostrata) and their prey species from the Antarctic and the North Pacific. Environmental Pollution, 98: 81-89.

Colborn, T. and M. J. Smolen (1996): Epidemiological analysis of persistent organochlorine contaminants in cetaceans. Reviews of Environmental Contamination and Toxicology, 146: 91-172.

George, J. L. and D. E. H. Frear (1966): Pesticides in the Antarctic. In Pesticides in the Environment and their Effects on Wildlife, N. W. Moore (ed.): 155-167, Journal of Applied Ecology (supplement).

Guruge, K.S., M. Watanabe, H. Tanaka and S. Tanabe (2001): Accumulation status of persistent organochlorines in albatrosses from the North Pacific and the Southern Ocean. Environmental Pollution, 114: 389-398.

Iwata, H., S. Tanabe, N. Sakai and R. Tatsukawa (1993): Distribution of persistent Organochlorines in the oceanic air and surface seawater and role of the ocean on their global transport and fate. Environmental Science and Technology, 27: 1080-1098.

Jones, P. D., D. J. Hannah, S. J. Buckland, P. J. Day, S. V. Leathem, L. J. Porter, H. J. Auman, J. T. Sanderson, C. Summer, J. P. Ludwig, T. L. Colborn and J. P. Giesy (1996): Persistent synthetic chlorinated hydrocarbons in albatross tissue samples from Midway Atoll. Environmental Toxicology and Chemistry, 15: 1793-1800.

Lahvis, G. P., R. S. Wells, D. W. Kuehl, J. L. Stewart, H. L. Rhinehart and C. S. Via (1995): Decrease lymphocyte responses in free-ranging bottlenose dolphins (Tursiops truncates) are associated with increased concentration of PCBs and DDT in peripheral blood. Environmental Health Perspectives, 103: 67-72.

Monirith, I. D. Ueno, S. Takahashi, H. Nakata, A. Sudaryanto, A. Subramanian, S. Karuppiah, A. Ismail, M. Muchtar, J. Zheng, B. J. Richardson, M. Prudente, N. D. Hue, A. V. Tkalin and S. Tanabe (2003): Asia-Pacific mussel watch: monitoring contamination of persistent organochlorine compounds in coastal warters of Asian countries, Marine Pollution Bulletin, 46: 281-300.

Nakata, H., S. Tanabe, R. Tatsukawa, M. Amano, N. Miyazaki and E. A . Petrov (1995): Persistent organochlorine residues and their accumulation kinetics in Baikal seal (Phoca sibirica) from Lake Baikal, Russia. Environmental Science and Technology, 29: 2877-2885.

O'Shea, T. J. and S. Tanabe (1999): Persistent ocean contaminants and marine mammals : a retrospective overview. In Proceedings of the Marine Mammal Commission Workshop Marine Mammals and Persistent Ocean Contaminants, T. J. O'Shea, R. R. Reeves and A.K. Long (eds.) : 87-92.

Prudente, M., S. Tanabe, M. Watanabe, A. Subramanian, N.
Miyazaki, P. Suarez and R. Tatsukawa ( 1997 ): Organochlorine contamination in some odontoceti species from the North Pacific and Indian Ocean. Marine Environmental Research, 44: 415-427.

Shaw, S. D. ( 1998): Organochlorines and biomarkers of immune and endocrine effects in Pacific harbour seal and Northern elephant seal pups. Ph.D Thesis of Colombia University School of Public Health.

Simmonds, M. ( 1991 ) : Marine mammal epizootics worldwide. In Proceedings of the Mediterranean Striped Dolphins Mortality International Workshop, X. Poster and M. Simmonds (ed.) : 9-19, Greenpeace International Mediterranean Sea Project, Madrid, Spain.

Sladen, W. J. L., C. M. Menzie and W. L. Reichel (1966): DDT residues in Adelie penguins and a crabeater seal from Antarctica. Nature, 210: 670-673.

Subramanian, An, S. Tanabe, R. Tatsukawa, S. Saito and N. Miyazaki (1987): Reduction in the testosterone levels by PCBs and DDE in Dall's porpoise of northwestern North Pacific. Marine Pollution Bulletin, 18: 643-649.

Tanabe, S. (1999): Butyltin contamination in marine mammals -a review. Marine Pollution Bulletin, 39: 393-398.

田辺信介 $(2002 \mathrm{a})$ : 環境省全国一斉調查の結果. かんきょ う, 27:9-11.

田辺信介 (2002 b) : POPsによるアジア途上国の母乳污 染. 生活衛生, 46: 229-235.

Tanabe, S., H. Iwata and R. Tatsukawa (1994): Global contamination by persistent organochlorines and their ecotoxicological impact on marine mammals. The Science of the Total Environment, 154, 163-177.

Tanabe, S., A. Ramesh, D. Sakashita, H. Iwata and R. Tatsukawa (1991): Fate of $\mathbf{H C H}$ (BHC) in tropical paddy field: application test in South India. International Journal of Environmental Analytical Chemistry, 45: 45-53.

Tanabe, S., J. Sung, D. Choi, N. Baba, M. Kyota, K. Yoshida and R. Tatsukawa (1994): Persistent organochlorine residues in northern fur seal from the Pacic coast of Japan since 1971. Environmental Pollution, 85: 305-314.

Tanabe, S., H. Tanaka and R. Tatsukawa ( 1984 ): Polychlorinated biphenyls, DDT, and hexachlorocyclohexane isomers in the western North Pacific ecosystem. Archives of Environmental Contamination and Toxicology, 13: 731738.

Tanabe, S., R. Tatsukawa, H. Tanaka, K. Maruyama, N. Miyazalki and T. Fujiyama (1981): Distribution and total burdens of chlorinated hydrocarbons in bodies of striped dolphins (Stenella coeruleoalba). Agricultural and Biological Chemistry, 45: 2569-2578.

Tanabe, S., S. Watanabe, H. Kan and R. Tatsukawa (1986): Capacity and mode of PCB metabolism in small cetaceans. Marine Mammal Science, 4:103-124. 